\title{
Transaksi Uang dan Dompet Digital Pada Saat Masa Pandemi Virus Corona (Covid-19)
}

\author{
Ade Parlaungan Nasution ${ }^{1}$, Ibnu Rasyid Munthe ${ }^{2 *}$, Bhakti Helvi Rambe ${ }^{3}$ \\ ${ }^{1,3}$ Fakultas Ekonomi dan Bisnis, Universitas Labuhanbatu, Rantauprapat, 21418, \\ ${ }^{2}$ Fakultas Sains dan Teknologi, Universitas Labuhanbatu, Rantauprapat, 21418. \\ 12adenasution@gmail.com, ${ }^{2}$ ibnurasyidmunthe@gmail.com*, ${ }^{3}$ bhaktihelvirambe@ gmail.com
}

\begin{abstract}
Abstrak
Pada umumnya seluruh penduduk di belahan benua mau pun antar negara mengalami keresahaan dan kepanikan akibat pandemi virus corona covid 19 yang menyebar cepat dan sampai sekarang belum ditemukan vaksinnya sehingga menimbulkan efek buruk baik kesehatan, serta ekonomi, Salah satu antisipasi penyebaran virus tersebut yakni melakukan transaksi elektronik atau digital maupun pembayaran digunakan dengan digitalisasi, maka dilakukan kajian ilmiah berupa penyebaran angket kepada masyarakat labuhanbatu sebanyak 143 orang dengan pengumpulan datanya, baik penyajian maupun menampilkan hasil data tersebut dengan cara menentukan nilainilai secara statistika, menyajikan informasi berupa data dalam bentuk diagram atau gambar mengenai hasil data dari presepsi masyarakat labuhanbatu dalam menggunakan transaksi digital pasca virus corona covid 19 data daat disajikan dalam bentuk yang lebih mudah dipahami atau dibaca (statistik Deskriftif). Hasil penelitian yang dilakukan memberikan informasi yakni Presepsi masyarakat tentang Dampak pasca virus corona covid-19 yang menyatakan Ada berdampak pasca virus corona (covid-19) sebesar 95 orang dengan persentase 66,4\%, Presepsi masyarakat tentang Dampak pasca virus corona (covid-19) pada penghasilan yang menyatakan menurun sebesar 91 orang dengan persentase $63,6 \%$, Presepsi masyarakat tentang berbelanja produk dengan transaksi digital setuju sebesar 57 orang menyatakan setuju persentasenya 39,9\%, Presepsi masyarakat tentang pembayaran tagihan menggunakan transaksi digital pasca virus corona covid 19. Presepsi masyarakat tentang pembayaran tagihan dengan menggunakan transaksi digital yang sebanyak 56 orang persentasenya 39,2\%, Presepsi masyarakat tentang pemesanan makanan online pasca virus corona covid 19 menyatakan setuju 49 orang persentase 34,3\%. masyarakat yang melakukan pemesanan transportasi online yang setuju 42 orang persentase $29,4 \%$, Presepsi masyarakat tentang tentang new normal menyatakan setuju 46 orang persentase $32,2 \%$.
\end{abstract}

Kata kunci : Presepsi Masyarakat, Dampak, Pasca Virus corona, Transaksi Digital, Statistik Deskriftif.

\begin{abstract}
In general, anxiety and fear are faced by all people in all parts of the continent and between countries due to the corona covid 19 virus pandemic that is spreading rapidly and a vaccine has not been identified until now that causes poor health and economic consequences. One of the hopes of the spread of the virus is to carry out electronic transactions or digital or payment is used by digitization, a scientific study is carried out by collecting data in the form of distributing questionnaires to the citizens of Labuanbatu up to 143 people, both presenting and showing the results of the data by statistically determining the values, presenting information data (descriptive statistics). The results of the research carried out provide details, namely the public perception of the effect of the post-corona covid-19 virus stating that there is an impact on income after the corona virus (covid19) by 95 individuals with a percentage of 66.4 percent, the public perception of the impact of the post-corona virus), stating that it decreased by 91 individuals with a percentage of 63.4 percent, The public perception of online food ordering after the corona covid virus 19 of the public perception of bill payment using digital transactions, which amounted to 56 people, the percentage was 39.2 percent, reported that 49 people approved, a percentage of 34.3 percent. People who order online transportation agree with 42 individuals, a percentage of 29.4 percent, a percentage of 32.2 percent, the public's view of the new normal states that 46 people agree,
\end{abstract}

\section{Keywords: Public Perception, Impact, Post-Corona Virus, Digital Transactions, Descriptive Statistics.}

\section{Pendahuluan}

Virus ini pertama kali dilaporkan pada badan WHO pada tanggal 31 Desember 2019 dan Negara pertama yang pertama terkonfirmasi merupakan Negara Cina, tepatnya dikota wuhan, tak terkecuali Indonesia, Indonesia turut serta menjadi bagian salah satu Negara yang terkena pendemi Virus Corona Covid 19. Virus corona adalah keluarga besar virus yang menyebabkan penyakit pada manusia dan hewan. Manusia umumnya menyebabkan infeksi pernafasan, mulai dari pilek hingga penyakit serius seperti Timur Tengah, sindrom pernafasan (MERS), dan sindrom pernafasan akut akut (SARS).[1]

Berdasarkan data resmi dari Gugus Tugas Percepatan Penanganan COVID-19 Republik Indonesia, jumlah kasus terkonfirmasi positif hingga 18 Juni 2020 adalah 41.431 orang dengan jumlah kematian 2.276 orang. Dari kedua angka ini dapat disimpulkan bahwa case fatality rate atau tingkat kematian yang disebabkan oleh COVID-19 di Indonesia adalah sekitar 5,5\%. Case fatality rate adalah presentase jumlah kematian dari seluruh jumlah kasus 
Jurnal Teknologi Informasi dan Komunikasi, ISSN : 2087-0868, Volume 12, Nomor 1, September 2021, Transaksi Uang dan Dompet Digital Pada Saat Masa Pandemi Virus Corona (Covid-19).

positif COVID-19 yang sudah terkonfirmasi dan dilaporkan. Dari seluruh penderita COVID-19 yang meninggal dunia, $0,8 \%$ berusia $0-5$ tahun, $0,5 \%$ berusia 6 17 tahun, $2,7 \%$ berusia $18-30$ tahun, $12,4 \%$ berusia $31-45$ tahun, $39,9 \%$ berusia $46-59$ tahun, dan $43,6 \%$ berusia 60 tahun ke atas. Sedangkan berdasarkan jenis kelamin, $60,8 \%$ penderita yang meninggal akibat COVID-19 adalah laki-laki dan 39,2\% sisanya adalah perempuan. Gejala awal infeksi virus Corona atau COVID-19 bisa menyerupai gejala flu, yaitu demam, pilek, batuk kering, sakit tenggorokan, dan sakit kepala. Setelah itu, gejala dapat hilang dan sembuh atau malah memberat. Penderita dengan gejala yang berat bisa mengalami demam tinggi, batuk berdahak bahkan berdarah, sesak napas, dan nyeri dada. Gejala-gejala tersebut muncul ketika tubuh bereaksi melawan virus Corona.[2]

Pengaruh penyebaran virus coronoa atau covid-19 sangat cepat dalam penyebarannya kepada manusia hampir seluruh dunia terinfeksi oleh virus ini, penyebarannya sangat cepat disebabkan adanya perilaku yang dilakukan setiap individu menyapa dan bersalaman satu sama lain atau menyentuh benda atau peralatan dengan kedua tangan kemudian tanpa sengaja menyentuh hidung maupun mata, sifat virus tidak bisa diketahui dengan mata sehingga setiap berinteraksi dilingkungan sekitar bisa saja terjangkit dari orang tanpa gejala atau orang yang positip corona yang beraktivitas diluar. Setiap hari manusia melakukan transaksi jual beli atau membeli kebutuhan kehidupan sehari-hari menggunakan media pembayaran dalam bentuk uang tunai atau uang kertas. Dengan uang kertas itu sebagai media penyebaran virus corona tidak dapat diketahui apakah uang tersebut bersih dari virus corona. Penyebaran virus ini yang sangat cepat dan mudah dalam penyebarannya maka badan kesehatan dunia atau who serta pemerintah melakukan antisipasi dengan protokol kesehatan serta bekerja dirumah. Seluruh penduduk didunia dengan wabah ini membuat resah dan takut untuk mengantisipasi penyebaran tersebut di negara Indonesia khususnya masyarakat kabupaten labuhanbattu harus menaati dan menjalankan protokol kesehatan yang disosialisasikan oleh badan kesehatan dunia atau who maupun Gugus Tugas Percepatan Penanganan Covid-19 Republik Indonesia yang tersebar diseluruh daerah indonesia. Salah satu antisipasi penyebaran virus tersebut yakni melakukan transaksi elektronik maupun pembayaran digunakan dengan digitalisasi, perlu dilakukan penelitian tentang bagaimana presepsi masyarakat labuhanbatu dalam penggunaan transaksi digital pasca virus corona atau covid-19.

\section{Dasar Teori}

\section{a. Teori tentang Presepsi Masyarakat}

Menurut Jalaludin Rakhmat bahawa presepsi mengamati sebuah objek baik peristiwa yang terjadi maupun menyimpulkan dari informasi yang terjadi dan menafsirkan pesan. Karakteristik persepsi terdiri dari:

a. Harus mempunyai Objek untuk dipersepsi.

b. Mengamati objek sebagai persiapan dalam mengadakan persepsi.

c. Memiliki alat indera/reseptor yaitu alat untuk menerima stimulus.

d. Memiliki Saraf sensoris sebagai alat untuk meneruskan stimulus ke otak, yang kemudian sebagai alat untuk mengadakan respon.
Menurut Miftah Toha faktor yang mempengaruhi persepsi seseorang antara lain:

a. Faktor internal: memiliki perasaan, sikap dan kepribadian individu, baik prasangka, keinginan ataupun harapan, perhatian (fokus), proses belajar, keadaan fisik, gangguan kejiwaan, nilai dan kebutuhan juga minat, maupun motivasi.

b. Faktor eksternal: mempunyai latar belakang keluarga, informasi yang diperoleh, pengetahuan dan kebutuhan sekitar, intensitas, ukuran, keberlawanan, pengulangan gerak, hal-hal baru dan familiar atau ketidak asingan suatu objek.

Setiap orang memiliki sifat kecenderungan dalam mengamati benda yang sama dengan cara yang berbedabeda. Perbedaan yang terjadi bisa dipengaruhi oleh banyak faktor seperti pengetahuan, pengalaman dan sudut pandangnya. Persepsi juga sebagai cara pandang seseorang terhadap suatu objek tertentu dengan cara yang berbeda-beda dengan menggunakan alat indera yang dimiliki, kemudian berusaha untuk menafsirkannya.[3]

\section{b. Teori Tentang Transaksi Digital}

Transaksi Digital adalah aktivitas tingkah laku yang dilakukan dengan menggunakan alat bantu berupa komputer baik menggunakan jaringan komputer sebagai alat komunikasi dengan bantuan media elektronik lainnya untuk mempermudah manusia dalam melakukan akivitas kehidupan sehari-hari. Dalam memanfaatkan transaksi digital pada saat ini sangat luas penggunaannya antara lain:

a. Perdagangan Elektronik (E-Commerce)

Menurut Laudon dan Traver E-commerce merupakan penggunaan internet, web, aplikasi seluler, dan browser yang berjalan pada perangkat seluler untuk bertransaksi bisnis. Secara digital memungkinkan transaksi komersial di antara organisasi dan individu. Manfaat perdagangan elektronik dengan membantu pengguna komputer, baik pengusaha (produser, pedagang, produsen) dan konsumen, untuk membeli dan menjual barang dan jasa serta transaksi dengan cepat dan mudah melalui Internet.[4].

b. Uang elekronik (E-money)

Uang elektronik sebagai metode pembayaran alternatif mempunyai kesamaan dengan uang tunai, masyaarakat dapat memanfaatkan untuk pembayaran. Uang elektronik sebagai pemabayaran dalam bentuk digital dengan kodekode tertentu dalam transaski pembayaran dan nilainya tetap sama. Dengan adanya uang elektronik dapat memberikan rasa nyaman, efesien serta dapat digunakan bersama secara global. Uang elektronik harus diakui oleh pemerintah dan harus lulus lembaga pengawas keuangan yang ditunjuk oleh pemerintah sehingga memberikan kenyamanan bagi pengguna uang elektronik tersebut[5].

Bank Indonesia mengeluarkan peraturan no 16/08/PBI/2014 tentang perubahan atas peraturan bank Indonesia no 11/12/PBI/2009 tentang uang elektronik pasal 1 ayat 3, yaitu:

1) Alat pembayaran yang memenuhi unsur diterbitkan atas dasar nilai uang yang diterbitkan dahulu kepada penerbit. 
2) Nilai uang disimpan secara elektronik dalam suatu media atau server.

3) Digunakan sebagai pembayaran kepada pedagang yang bukan merupakan penerbit uang tersebut.

4) Nilai uang elektronik yg dikelola penerbit bukan sebagai simpanan.[6]

\section{c. Dompet Digital (E-Wallet)}

Berkembangnya uang elektronik menjadi pilihan masyarakat untuk melakukan pembayaran atau pembelian tanpa mengunakan uang tunai, sehingga untuk menyimpan sejumlah uang elektronik yang dimiliki oleh masyakat sering disebut dengan dompet digital. Dompet digital sebuah produk layanan uang elektronik yang disimpan dan siap digunakan, mudah, cepat, dan aman.[7]

\section{c. Teori tentang Virus Corona Covid-19}

Corona viruses $(\mathrm{CoV})$ merupakan bagian dari keluarga virus yang menyebabkan penyakit mulai dari flu hingga penyakit yang lebih berat seperti Middle East Respiratory Syndrome (MERS-CoV) and Severe Acute Respiratory Syndrome (SARS-CoV). Penyakit yang disebabkan virus corona, atau dikenal dengan COVID-19. Kasus Coronavirus pertama kali muncul dan menyerang orang-orang di Wuhan, Cina. Pneumonia dengan gejala mirip flu umumnya dianggap sebagai kasus pertama. Gejala-yang terjadi seperti batuk, demam, kelelahan, sesak napas dan kehilangan nafsu makan. Namun, tidak seperti influenza, coronavirus berkembang dengan cepat dan dapat menyebabkan infeksi yang lebih serius dan kegagalan organ. Keadaan darurat ini terutama terjadi pada pasien yang sebelumnya memiliki masalah kesehatan. Karena transmisi coronavirus yang cepat, Organisasi Kesehatan Dunia (WHO) mengklasifikasikan coronavirus sebagai pandemi pada 11 Maret 2020. Dunia dijamin akan lolos dari coronavirus. Virus Corona menyebar dengan mudah dan menginfeksi orang-orang dari segala usia. Virus dapat dengan mudah ditularkan melalui kontak dengan korban. Sayangnya, tidak ada obat khusus untuk mengobati kasus infeksi coronavirus atau COVID-19. Untuk mengantisipasi penyebaran catatan medis, mereka harus dikeluarkan oleh pemerintah dan otoritas kesehatan global.[9]

\section{Metodologi Penelitian}

Melakukan penelitian ini untuk mengetahui presepsi masyarakat labuhanbatu dalam penggunaan dalam transaksi digital pasca virus corona covid19, mempelajarinya dengan cara mengumpulkan data dan memberikan informasi dalam penyajian data sehingga muda dipahami yang berhubungan dengan penelitian yang terjadi serta menguraikan atau memberikan keteranganketerangan mengenai hasil dari penelitian berupa data atau keadaan atau fenomena. Metode penelitian ini berupa statistik deskriptif yang berfungsi memberikan informasi tentang keadaan, gejala, atau persoalan yang diteliti. Menurut Pangestu Subagyo bahwa statistika deskriptif adalah bagian statistika mengenai pengumpulan data, penyajian, penentuan nilai-nilai statistika, pembuatan diagram atau gambar mengenai sesuatu hal, disini data yang disajikan dalam bentuk yang lebih mudah dipahami atau dibaca.[10]. Hasil pengolahan data dilakukan dalam bentuk penyebaran kuisioner pada masyarakat sampel data sebanyak 143 orang dengan mengisi kuisioner tersebut maka data yang diperoleh dari pengolahan data terebut diolah dengan aplikasi statistik.

\section{Hasil dan Pembahasan}

Virus corona covid-19 sudah menyebar ke seluruh dunia, yang bermula dari wuhan di negara cina, perkembangan begitu pesat yang menyebabkan kematian yang meningkat dan penduduk terinfeksi dari penyebarannya melalui interaksi manusia ke manusia atau virus tersebut melekat pada benda-benda dilingkungan sekitar penduduk. Salah satu untuk mengantisipasi perkembangan virus tersebut melalui mengurangi penggunaan uang secara tunai dengan menggunakan transaksi digital. Transaksi digital ini menjadi salah satu cara pencegahannya disebabkan tidak ada interaksi secara fisik satu dengan yang lain, melainkan interaksi menggunakan sebuah teknologi yang sudah berkembang saat ini baik pada smartphone maupun laptop atau perangkat elektronik yang saling berhubungan dengan teknologi internet. Maka disini peneliti tertarik melakukan penelitian pada masyarakat khsususnya kabupaten labuhanbatu dalam pengggunaan transaksi digital pasca virus corona covid 19 yang melanda sektar tiga bulan. Melalui perspektif masyarakat labuhanbatu pada fenomena yang terjadi. Sehingga hasil penelitian ini memberikan informasi berupa pengetahuan terhadap transaksi digital atau elektronik.

a) Data Penduduk Labuhanbatu berdasarkan tempat tinggal

Masyarakat Labuhanbatu yang berpartisipasi dalam penelitian ini bertempat tinggal di kecamatan yang ada di Labuhanbatu sehingga data tersebut dapat diinformasikan berdasarkan kecamatan sesuai dengan tempat tinggal masyarakat.

Tabel 1. Kecamatan Di Labuhanbatu

\begin{tabular}{|c|c|c|c|c|}
\hline & & Frequency & Percent & $\begin{array}{c}\text { Valid } \\
\text { Percent }\end{array}$ \\
\hline \multirow[t]{18}{*}{ Valid } & Bilah & 6 & 4.2 & 4.2 \\
\hline & Barat & & & \\
\hline & Bilah & 13 & 9.1 & 9.1 \\
\hline & Hilir & & & \\
\hline & Bilah & 28 & 19.6 & 19.6 \\
\hline & Hulu & & & \\
\hline & Panai & 3 & 2.1 & 2.1 \\
\hline & Hilir & & & \\
\hline & Panai & 4 & 2.8 & 2.8 \\
\hline & Hulu & & & \\
\hline & Panai & 4 & 2.8 & 2.8 \\
\hline & Tengah & & & \\
\hline & Pangkatan & 9 & 6.3 & 6.3 \\
\hline & Rantau & 43 & 30.1 & 30.1 \\
\hline & Selatan & & & \\
\hline & Rantau & 33 & 23.1 & 23.1 \\
\hline & Utara & & & \\
\hline & Total & 143 & 100.0 & 100.0 \\
\hline
\end{tabular}

Tabel1. Kecamatan di Labuhanbatu dapat diperoleh informasi bahwa sebaran masyarakat tersebut yang berpartisipasi dalam penelitian ini meliputi kecamatan rantau selatan dimana masyarakatnya yang berpartisipasi sebesar 43 orang dengan persentase sebesar $30,1 \%$ lebih dominan mengikuti pendataan ini, Selanjutnya Kecamatan rantau utara dimana masyarakat yang berpartisipasi sebesar 33 orang dengan persentase sebesar $23,1 \%$, Selanjutnya 
Jurnal Teknologi Informasi dan Komunikasi, ISSN : 2087-0868, Volume 12, Nomor 1, September 2021, Transaksi Uang dan Dompet Digital Pada Saat Masa Pandemi Virus Corona (Covid-19).

kecamatan Bilah hulu dimana masyarakat yang berpartisipasi sebesar 28 orang dengan persentase sebesar $19,6 \%$ sedangkan yang paling rendah yakni kecamatan panai hilir sebar 3 orang dengan persentase sebesar $2,1 \%$.

b) Data Penduduk Labuhanbatu berdasarkan Jenis Pekerjaan

Masyarakat Labuhanbatu yang berpartisipasi dalam penelitian ini yang berkerja di daerah Labuhanbatu sehingga data tersebut dapat memberikan informasi berdasarkan jenis pekerjaan yang ada di Labuhanbatu

Tabel 2. Jenis Pekerjaan

\begin{tabular}{rlrr}
\hline \multirow{6}{*}{ Valid } & Frequency & Percent \\
& ASN/PNS & 19 & 13.3 \\
& Karyawan Swasta & 45 & 31.5 \\
& Mahasiswa/Pelajar & 26 & 18.2 \\
& Petani & 12 & 8.4 \\
& Tidak Bekerja & 5 & 3.5 \\
& Wiraswasta & 36 & 25.2 \\
& Total & 143 & 100.0 \\
\hline
\end{tabular}

Tabel 2. Jenis Pekerjaan memberikan informasi data dari hasil penelitian yang dilakukan bahwa di kabupaten labuhanbatu sebaran data yang berdasarkan jenis pekerjaan yang lebih tinggi yang berpartisipasi yakni masyarakat Labuhanbatu yang berkerja sebagai Karyawan Swasta sebanyak 45 orang dengan persentasenya sebesar $31,5 \%$, selanjutnya bekerja sebagai wiraswasta sebanyak 36 orang dengan persentase sebesar $25,2 \%$, selanjutnya yang paling rendah tidak bekerja 5 orang dengan persentase $3,5 \%$.

c) Dampak Pasca Virus Corona (Covid-19) pada Penghasilan Masyarakat Labuhanbatu Hasil penelitian yang dilakukan dikabupaten labuhanbatu dampak pasca virus corona (Covid-19) pada penghasilan masyarakat Labuhanbatu pada tabel 4. Dampak Pasca Virus Corona (Covid-29) pada penghasilan

Tabel 4. Dampak Pasca Virus CoronaPada Penghasilan

\begin{tabular}{llrrr}
\hline \multirow{6}{*}{ Valid } & Frequency & Percent & $\begin{array}{c}\text { Valid } \\
\text { Percent }\end{array}$ \\
& Meningkat & 12 & 8.4 & 8.4 \\
& Menurun & 91 & 63.6 & 63.6 \\
& Tidak ada & 40 & 28.0 & 28.0 \\
& dampak & & & \\
& Total & 143 & 100.0 & 100.0 \\
\hline
\end{tabular}

Tabel 4. Dampak Pasca Virus Corona (Covid-19) pada penghasilan masyarakat labuhanbatu memberikan informasi data dari hasil penelitian yang dilakukan di Kabupaten Labuhanbatu sebaran data dampak pasca virus corona (covid-19) pada penghasilan yang menyatakan menurun sebesar 91 orang dengan persentase $63,6 \%$, selanjutnya yang menyatakan tidak berdampak sebesar 40 orang dengan persentase $28,6 \%$, dan yang menyatakan meningkat sebesar 12 orang dengan persentase $8,4 \%$.

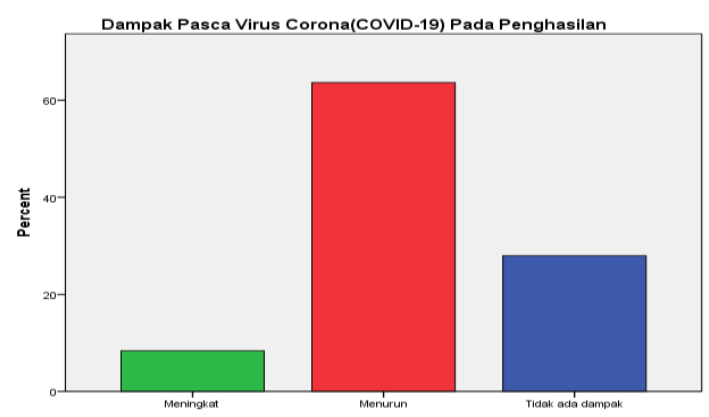

Gambar 2. Dampak Pasca Virus Corona(COVID-19) Pada Penghasilan

d) Berbelanja Produk dengan menggunakan Transaksi Digital Pasca Virus Corona (Covid-19) Hasil penelitian yang dilakukan dikabupaten labuhanbatu berbelanja produk dengan menggunakan transaksi digital pasca virus corona (covid-19) pada masyarakat Labuhanbatu tabel 5. Berbelanja Produk dengan transaksi digital.

Tabel 5. Berbelanja Produk dengan transaksi digital

\begin{tabular}{rlrrr}
\hline \multirow{6}{*}{ Valid } & Frequency & Percent & \multicolumn{1}{c}{ Valid } \\
Percent
\end{tabular}

Tabel 5. Berbelanja produk dengan transaksi digital memberikan informasi data dari hasil penelitian dilakukan di kabupaten labuhanbatu sebaran data yang diperoleh yakni masyakat yang setuju berbelanja produk dengan transaksi digital sebesar 57 orang menyatakan setuju persentasenya $39,9 \%$, selanjutnya yang menyatakan sangat setuju sebesar 14 orang persentase $9,8 \%$, selanjutnya yang menyatakan netral 26 orang persentase $18,2 \%$, selanjutnya yang menyatakan kurang setuju sebesar 30 orang persentase $21 \%$, dan yang menyatakan tidak setuju sebesar 16 orang persentase $11,2 \%$.

e) Pembayaran Tagihan Menggunakan Transaksi Digital Pasca Virus Corona (covid-19)

Hasil penelitian yang dilakukan dikabupaten labuhanbatu pembayaran tagihan menggunakan transaksi digital pasca virus corona (covid-19) pada masyarakat Labuhanbatu tabel 6. Pembayaran Tagihan Menggunakan Transaksi Digital

Tabel 6. Pembayaran Tagihan Menggunakan Transaksi Digital

\begin{tabular}{|c|c|c|c|c|}
\hline & & Frequency & Percent & $\begin{array}{c}\text { Valid } \\
\text { Percent }\end{array}$ \\
\hline Valid & $\begin{array}{l}\text { Kurang } \\
\text { Setuju, }\end{array}$ & 19 & 13.3 & 13.3 \\
\hline
\end{tabular}


Jurnal Teknologi Informasi dan Komunikasi, ISSN : 2087-0868, Volume 12, Nomor 1, September 2021, Transaksi Uang dan Dompet Digital Pada Saat Masa Pandemi Virus Corona (Covid-19).

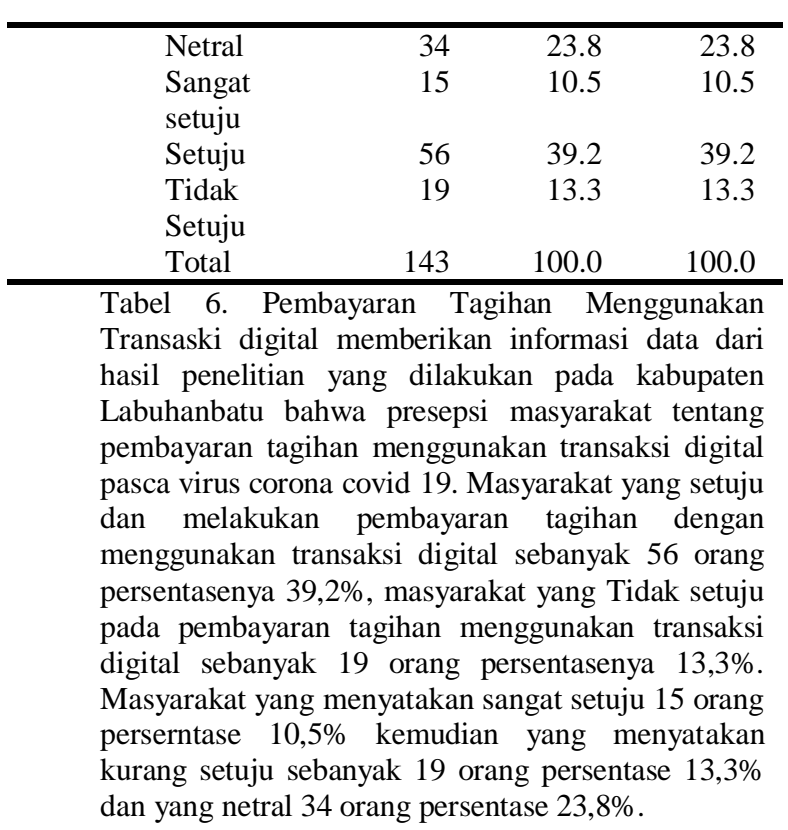

f) Pemesanan Makanan Online menggunakan transaksi digital Pasca Virus Corona (covid-19)

Hasil penelitian yang dilakukan dikabupaten labuhanbatu pembayaran tagihan menggunakan transaksi digital pasca virus corona (covid-19) pada masyarakat Labuhanbatu tabel 7 . pemesanan makanan online menggunakan transaksi digital

Tabel 7. Pemesanan Makanan Online menggunakan transaksi digital.

\begin{tabular}{|c|c|c|c|c|}
\hline & & Frequency & Percent & $\begin{array}{c}\text { Valid } \\
\text { Percent }\end{array}$ \\
\hline \multirow{8}{*}{ Valid } & Kurang & 21 & 14.7 & 14.7 \\
\hline & Setuju & & & \\
\hline & Netral & 35 & 24.5 & 24.5 \\
\hline & Sangat & 11 & 7.7 & 7.7 \\
\hline & $\begin{array}{l}\text { setuju } \\
\text { Setuiu }\end{array}$ & 49 & 343 & 343 \\
\hline & Tidak & 27 & 18.9 & 18.9 \\
\hline & Setuju & & & \\
\hline & Total & 143 & 100.0 & 100.0 \\
\hline
\end{tabular}

Tabel 7. Pemesanan Makanan Online menggunakan transaski digital informasi diketahui bahwa masyarakat labuhanbatu yang melakukan pemesanan makanan online pasca virus corona covid 19 menyatakan sangat setuju 11 orang pesentase $7,7 \%$ kemudian yang menyatakan setuju 49 orang persentase $34,3 \%$ dan yang menyatakan kurang setuju 21 orang persentase $14,7 \%$ serta yang tidak setuju 27 orang persentase $18,9 \%$, masyarakat yang menyatakan netral 35 orang persentase $24,5 \%$.

\section{g) Pemesanan Transportasi Online dengan menggunakan transaksi digital Pasca Virus Corona (covid-19)}

Hasil penelitian yang dilakukan dikabupaten labuhanbatu pemesanan transportasi online menggunakan transaksi digital pasca virus corona (covid-19) pada masyarakat Labuhanbatu tabel 8. Pemesanan Transportasi Online menggunakan transaksi digital.

Tabel 8. Pemesanan Transportasi Online Menggunakan Transaksi Digital

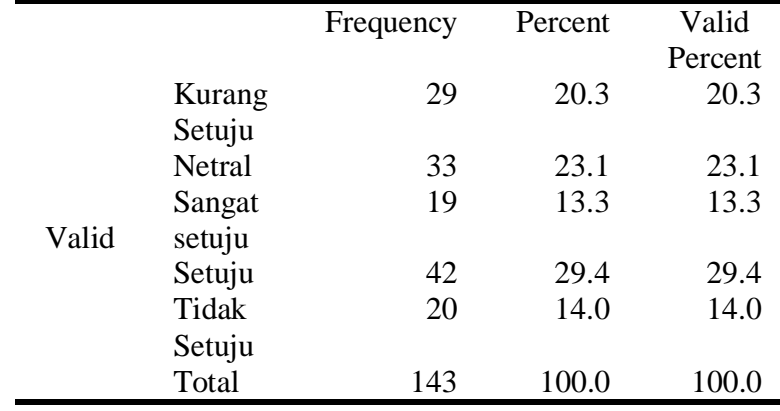

Tabel 8. Pemesanan Transportasi Online menggunakan transaksi digital memberikan informasi bahwa masyarakat yang melakukan pemesanan transportasi online yang setuju 42 orang persentase $29,4 \%$, sangat setuju 29 orang persentase $13,3 \%$. Kemudian masyarakat yang menyatakan tidak setuju 20 orang persentase $14 \%$ dan kurang setuju 29 orang persentase $20,3 \%$ sedangkan masyarakat yang netral 33 orang pesentase $23,1 \%$.

h) Strategi pemerintah tentang new normal pasca virus corona (covid-19)

Hasil penelitian yang dilakukan dikabupaten labuhanbatu tentang strategi pemerintah new normal pasca virus corona (covid-19) pada masyarakat Labuhanbatu Tabel 9. Strategi pemerintah tentang new normal pasca virus corona (covid-19),

Tabel 9. Strategi pemerintah tentang new normal pasca virus corona (covid-19)

\begin{tabular}{clrrr}
\hline \multirow{6}{*}{ Valid } & Frequency & Percent & \multicolumn{1}{c}{ Valid } \\
Percent \\
& Kurang & 23 & 16.1 & 16.1 \\
& Setuju & & & \\
& Netral & 24 & 16.8 & 16.8 \\
& Sangat & 18 & 12.6 & 12.6 \\
& setuju & & & \\
& Setuju & 46 & 32.2 & 32.2 \\
& Tidak & 32 & 22.4 & 22.4 \\
& Setuju & & & \\
& Total & 143 & 100.0 & 100.0 \\
\hline
\end{tabular}

Tabel 9. Strategi pemerintah tentang new normal pasca virus corona (covid-19) dapat diketahui informasi bahwa masyarakat labuhanbatu tentang new normal menyatakan sangat setuju 18 orang persentase 12, 6\% kemudian setuju 46 orang persentase $32,2 \%$. Serta masyarakat labuhanbatu yang kurang setuju 23 orang persentase $16,1 \%$, tidak setuju 32 orang perentase $22,4 \%$ sedangkan masyarakat yang menyatakan netral terhadap strategi pemerintah new normal 24 orang persentase $16,8 \%$.

\section{Kesimpulan}

Pada umumnya seluruh penduduk di belahan benua mau pun antar negara mengalami keresahaan dan kepanikan akibat pandemi virus corona covid 19 yang menyebar cepat dan sampai sekarang belum ditemukan vaksinnya sehingga menimbulkan efek buruk baik kesehatan, serta ekonomi, Salah satu antisipasi penyebaran virus tersebut yakni melakukan transaksi elektronik atau digital maupun pembayaran digunakan dengan digitalisasi, maka dilakukan kajian ilmiah berupa penyebaran angket kepada masyarakat labuhanbatu sebanyak 143 orang dengan 
Jurnal Teknologi Informasi dan Komunikasi, ISSN : 2087-0868, Volume 12, Nomor 1, September 2021, Transaksi Uang dan Dompet Digital Pada Saat Masa Pandemi Virus Corona (Covid-19).

pengumpulan datanya, baik penyajian maupun menampilkan hasil data tersebut dengan cara menentukan nilai-nilai secara statistika, menyajikan informasi berupa data dalam bentuk diagram atau gambar mengenai hasil data dari presepsi masyarakat labuhanbatu dalam menggunakan transaksi digital pasca virus corona covid 19 data daat disajikan dalam bentuk yang lebih mudah dipahami atau dibaca (statistik Deskriftif). Hasil penelitian yang dilakukan memberikan informasi yakni Presepsi masyarakat tentang Dampak pasca virus corona covid-19 yang menyatakan Ada berdampak pasca virus corona (covid-19) sebesar 95 orang dengan persentase $66,4 \%$, Presepsi masyarakat tentang Dampak pasca virus corona (covid-19) pada penghasilan yang menyatakan menurun sebesar 91 orang dengan persentase 63,6\%, Presepsi masyarakat tentang berbelanja produk dengan transaksi digital setuju sebesar 57 orang menyatakan setuju persentasenya 39,9\%, Presepsi masyarakat tentang pembayaran tagihan menggunakan transaksi digital pasca virus corona covid 19. Presepsi masyarakat tentang pembayaran tagihan dengan menggunakan transaksi digital yang sebanyak 56 orang persentasenya $39,2 \%$, Presepsi masyarakat tentang pemesanan makanan online pasca virus corona covid 19 menyatakan setuju 49 orang persentase $34,3 \%$. masyarakat yang melakukan pemesanan transportasi online yang setuju 42 orang persentase $29,4 \%$, Presepsi masyarakat tentang tentang new normal menyatakan setuju 46 orang persentase $32,2 \%$

\section{Daftar Pustaka:}

[1] R. Pakpahan and Y. Fitriani, "ANALISA

PEMANFAATAN TEKNOLOGI INFORMASI DALAM PEMBELAJARAN JARAK JAUH DI TENGAH PANDEMI VIRUS CORONA COVID-19," JISAMAR (Journal Inf. Syst. Applied, Manag. Account. Researh), vol. 4, no. 2, pp. 30-36, 2020, [Online]. Available: http://journal.stmikjayakarta.ac.id/index.php/ jisamar/article/view/181/144.

[2] M. D. C. Pane, "Virus Corona - Gejala, Penyebab, dan Mengobati." https://www.alodokter.com/virus-corona (accessed Jun. 18, 2020).

[3] S. Hermuningsih and K. Wardani, "PERSEPSI MAHASISWA TERHADAP METODE SIMULASI ONLINE TRADING DI BURSA EFEK INDONESIA DI FAKULTAS EKONOMI
YOGYAKARTA,” EKOBIS, vol. 17, no. 2, pp. 199-207, 2016, [Online]. Available: http://1ppm-

unissula.com/jurnal.unissula.ac.id/index.php /ekobis/article/viewFile/1332/1032.

[4] Maria Chyntia Chrystiantari and A. Suyanto, "ANALISIS FAKTOR-FAKTOR PEMBENTUK CUSTOMER PERCEIVED VALUE E-COMMERCE DI INDONESIA," JMM Online, vol. 4, no. 2, pp. 215-224, 2020.

[5] A. Damara and A. Suyanto, "ANALYSIS OF FACTOR THAT CONSTRUCT INDONESIAN'S SOCIETY USING ELECTRONIC MONEY," in $e$-Proceeding of Management, 2019, vol. 6, no. 2, pp. 1961-1967.

[6] Pranoto and S. S. Salsabila, "Eksistensi Kartu Kredit Dengan Adanya Electronic Money (E-Money) Sebagai Alat Pembayaran Pembayaran Yang Sah," Priv. Law, vol. 6, no. 1, pp. 24-33, 2018.

[7] I. Kumala and I. Mutia, "PEMANFAATAN APLIKASI DOMPET DIGITAL TERHADAP TRANSAKSI RETAIL MAHASISWA," in Seminar Nasional Riset dan Teknologi (SEMNAS RISTEK) 2020 , 2020, pp. 64-69.

[8] A. Setiawan, R. K. Fanny, and I. B. Yudistira, "Diseminasi Hukum Hak Cipta pada Produk Digital di Kota Semarang," Pengabdi. Huk. di Indones., p. 14, 2018, [Online]. Available:

https://journal.unnes.ac.id/sju/index.php/JPH I/index.

[9] N. Mona, "KONSEP ISOLASI DALAM JARINGAN SOSIAL UNTUK MEMINIMALISASI EFEK CONTAGIOUS ( KASUS PENYEBARAN VIRUS CORONA DI INDONESIA )," J. Sos. Hum. Terap., vol. 2, no. 2, pp. 117-125, 2020.

[10] L. M. Nasution, "STATISTIK DESKRIPTIF," J. Hikmah, vol. 14, no. 1, pp. 49-55, 2017. 